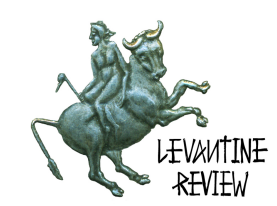

\title{
ON THE HORNS OF A DILEMMA: INTELLECTUALS BETWEEN THE REGIME AND THE PEOPLE AS REFLECTED IN IRAQI COMMUNIST LITERATURE
}

\author{
Hilla Peled-Shapira*
}

\begin{abstract}
This paper deals with the way in which Communist writers in mid-twentiethcentury Iraq used literature in order to, on the one hand express their tense relationship with the regime during times of severe political repression, and on the other hand sharply criticize the Iraqi people themselves for not taking responsibility for or caring about their fate-or, for that matter, for failing to internalize the social class discourse to which the Communists aspired. The paper's objective is to examine the connection between the writers' ideology and the rhetorical and conceptual elements with which they expressed their dissatisfaction with the regime, the way Iraqi society was run, and the desires of bothintellectuals and society at large - to undergo change. In addition, this study will survey the esthetic and stylistic devices, which the writers under consideration chose, and consider both the meanings and motives behind their choices. These aspects will be examined in the framework of a proposed model of "circles of criticism."
\end{abstract}

\section{Background and Research Hypothesis}

In retrospect the revolutions of the "Arab Spring" are in a sense reminiscent of waves of rebellion and resistance that occurred in mid-twentieth century Middle East, and the affected regimes' reactions to them-although, of course, the circumstances then as now are quite different, as are the respective underlying motivations of the revolutionaries.

If we take Iraq as an example and focus on one of the stormier periods in its political history, namely the mid-twentieth century and subsequent to that, we note both extensive intellectual activity and violent official repression of intellectuals who refused to cooperate with the regime. In this period leftists, including Communists, were severely persecuted on account of their rebellious mindset, both before and after Iraq became a republic in 1958. To wit, meetingplaces where leftist writers and thinkers were known to congregate were shut down, the intellectuals in question were dismissed from their jobs, and were often times subjected to arrest, imprisonment, torture, exile, execution, or were simply made to "disappear" from the face of the earth. ${ }^{1}$ Thus the Iraqi poet Fadel

\footnotetext{
${ }^{1}$ See, for example, the trial of Kamel al-Jadarji, the head of the Iraqi National Democratic Party and the editor of its official organ, on charges of incitement: Fawzi, Aḥmad, "Muhāāamat șawt al-ahālī lisān al-ḥizb al-waṭan̄̄ al-dīmūqrāṭ̄ - Kamel al-Jadarji 1946" ("The trial of Sawt al-ahālī, organ of the National Democratic Party, Kamel al-Jadarji 1946"), Ashhar al-muhākamāt al-ṣuhufiyya fì l-'Irāq (The most prominent press trials in Iraq), Baghdad, 1985, pp. 47-78.
} 


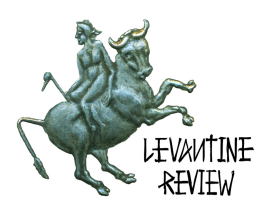

al- 'Azzawi, for example, in his book on Communism in Iraq in the 1960s, wrote that the regime gave the intellectuals the feeling that they were an inferior class of citizens, to be treated like dogs, until and unless they agreed to serve the Baath Party—this after being subjected to severe physical abuse and torture. According to al- 'Azzawi hundreds of intellectuals were tortured until they agreed to cooperate with the party and its security and intelligence organs. ${ }^{2}$

We assume that in addition to their purely political activities, leftist writers, including the Communists, channeled their frustration at the system of government in Iraq, their fears, their sense of alienation and their persecutions, into their works and used their compositions as both sociopolitical manifestos and as a vehicle for expressing their feelings of being persecuted. In this essay, we will explore the artistic mediums the intellectuals in question chose and the specific imagery they used, and propose a model of "circles of criticism" within which we shall be able to present a classification of the criticisms expressed by these intellectuals. Our analysis of the modes of artistic expression chosen by these writers is based on the assumption that over time the similes and metaphors which they used underwent a transformation from the concrete and conventional in Classical Arabic poetry to the personal and symbolic in modern Arabic literature, and that the decipherment of their symbolism can illuminate the relationship between the intellectuals and the regime as well as that between the intellectuals and the people among whom they lived. ${ }^{3}$

\section{The model of circles of criticism}

One of the main functions of intellectuals is to serve as social reformers. In order to fulfill this function they cast doubt on the existing norms of their society and criticize their surroundings, their social and political developments, and occasionally themselves.

An examination of the works of Communist writers who left Iraq for ideological reasons in the middle of the twentieth century reveals a typical pattern that we shall present below; a pattern that implies criticisms of various types. The term "implies" suits this model, since in these works things are often not said clearly and explicitly but are transmitted to the reader in the process of literary communication through sophisticated imagery and other artistic devices, which the reader is required to decipher one by one in order to be able to understand the message as a whole.

\footnotetext{
${ }^{2}$ Al-'Azzawi, Fadel, al-Rūḥ al-ḥayya - jūl al-sittīnāt fì al- 'Irāq (The Living Spirit: The Generation of the 1960s in Iraq), Beirut, 1997, pp. 271-272.

${ }^{3}$ On this process whereby conventional metaphors took on a personal emotional aspect, see: Moreh, Shmuel, "An Outline of the Development of Modern Arabic Literature", in: Idem, Studies in Modern Arabic Prose and Poetry, Leiden, 1988, p. 67; Peled-Shapira, Hilla, "From Conventional to Personal, or: What Happened to Metaphor under the Influence of Ideology - The Case of Ghā'ib Tu'ma Farmān", JSS, LIV/1 spring 2009, pp. 227 - 249.
} 


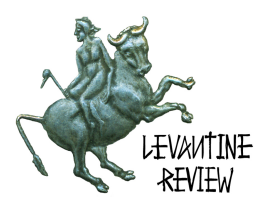

The model of circles of criticism will be exemplified with the works of two émigré opposition authors, the writer Ghā ' ib Ṭ ' ma Farmān (Baghdad, 1927 Moscow, 1990) ${ }^{4}$ and the Kurdish-Iraqi poet Buland al-Haydari (Baghdad, 1926 London, 1996.) 5 The two were contemporaries; both were Communists and were persecuted for that reason; both were arrested and went into exile; and both died in their respective places of exile. ${ }^{6}$ Farmān was born into a poor family and suffered all his life from economic and health problems, whereas al-Haydari issued from an aristocratic milieu and was befriended by intellectuals and ordinary people alike.

Socially and culturally Buland al-Haydari was a member of a literary group called the "Temps Perdu Group" (Jamaat al-waqt al-da 'i '), to which Ghā' ib Ṭu 'ma Farmān had affinities as well, although he was not a member. The group's

\footnotetext{
${ }^{4}$ On Farmān's life and oeuvre, see: Starkey, Paul, Modern Arabic Literature, Edinburgh, 2006, pp. 130 - 131; Walther, W., Farman,Gha'ib Tu'ma", in: Meisami, Julie Scott and Starkey, Paul, Encyclopedia of Arabic Literature, London \& New York, 1998, pp. 221 - 222; Allen, Roger, Modern Arabic Literature, New York, 1987, pp. 96 - 100; Bashkin, Orit, The Other Iraq, Stanford, 2009, pp. 88 - 89; Campbell, Robert B., Contemporary Arab Writers: Biographies and Autobiographies (in Arabic), Beirut 1996, pp. 1046-1047; Ibrahim 'Ali, al-Zamān wal-makān fì riwāyāt Ghā'ib Tứma Farmān

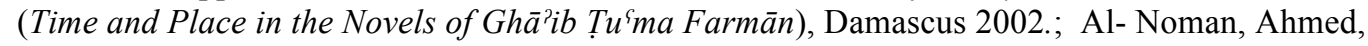
Ghaeb Toma Faraman (in Arabic), Beirut 1996; Al-Masri, Khaled, Gha'eb Tou'mah Faraman- The Society Movement and the Change of the Text (in Arabic), Beirut 1997; Shlaiba, Zouhair, Gha'ib Tu'mah Farman - A Comparative Study on the Iraqi Novel (in Arabic), Beirut 1996.

Here is a list of his works: Two short-story collections, Hașīd al-rahāa (Grindstone Harvest), Baghdad 1954 and Mawlüd ākhar (Another Newborn), Baghdad 1959; and the novels al-Nakhla wal-jīrān (The Palm Tree and the Neighbours), Beirut 1965, Khamsat așwāt (Five Voices), Beirut 1967, al-Makhād (Labour Pains), Baghdad 1974, al-Qurbān (The Sacrifice), Baghdad 1975, Zilāl 'alā al-nāfidha (Shadows on the Window), Beirut 1979, Ālām al-sayyid Ma'rūf (Mr. Ma'rūf's Pains), Beirut 1982, alMurtajā wal-mu'ajjal (The Yearned for and the Postponed, Beirut 1986, and al-Markab (The Ship), Beirut 1989.

${ }^{5}$ For details about al-Haydari's life, family and art, see: Ajami, Fouad, The Dream Palace of the Arabs -A Generation's Odyssey, New York, 1998, pp. 3-9, 79; Basri, Meer S., Life's Journey from the Banks of the Tigris to the Valley of the Thames, Jerusalem, 1992, p. 91 Jabra, Jabra Ibrahim, Shāri al-amīrāt [Amīrāt street], Beirut, 1994, pp. 123-124; Campbell, pp. 519-520; Moreh, Shmuel, "Ideological Trends in Al-Shi'r Al-Hurr" in: Idem, Modern Arabic Poetry 1800 - 1970, Leiden, 1976, p. 271. Al- Haydari's poetry collections: Khafqat al-ținn (Clay Pulse, Baghdad, 1946), Aghānī al-madīna almayyita (Songs of the Dead City, Baghdad, 1951), Aghānī al-madīna al-mayyita wa-qașāi id ukhrā (Songs of the Dead City and Other Poems, Baghdad, 1957), Khutuwāt fì al-ghurba (Steps in Exile, Sidon, 1965), Riḥlat al-ḥurūf al-ṣufr (Journey of the Yellow Letters, Beirut, 1968), Aghānī al-hāris almut $^{\varsigma} a b$ (Songs of the Tired Guard, Beirut, 1971), Hiwār ' ${ }^{`}$ abra al-ab ${ }^{\varsigma} \bar{d}$ al-thalātha (Dialogue across Three Dimensions, Baghdad, 1972), Ilā Bayrūt ma'a tahiyyātī (To Beirut with Greetings, Cairo, 1984, London 1989), Abwāb ilā al-bayt al-dayyiq (Doors to the Narrow House, London, 1990), al-A'māl alkāmila (Complete Works, Beirut 1974, Damascus 1992).

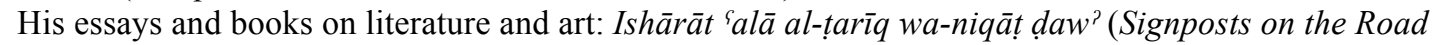
and Points of Light, Beirut, 1980), Zaman li-kull al-azmina: nazarāt wa-ārā? fì al-fann (A Time for All Times: Views and Opinions on Art, Beirut, 1981), Madākhil ilā al-shi'r al-`irāqī al-hadìth (Introductions to Modern Iraqi Poetry), Cairo, 1987.

The excerpts from al-Haydari's poems quoted in this article are taken from his Complete Works (alA'māl al-kāmila), Damascus, 1992.

${ }^{6}$ On other Iraqi writers who went into exile and their works, see: Jasim, Abed, al-Dhākira wal-hanīn fi al-qișșa al-'irāqiyya al-qașīra fì al-manfā (Memory and Nostalgia), London, 1996.
} 
members debated current events and discussed literary and cultural issues with a view to promote the arts in Iraq. ${ }^{7}$ Both al-Haydari and Farmān were thus involved in Iraq's intellectual life and were familiar with novel ways of thought in literature, art, and politics.

In both their works, both writers evoked a fascinating picture of what it was like to be a persecuted leftist intellectual. They also expressed their views on the alternative way that the state should be run. As leftist writers, they placed the simple man at the top of their agenda. In short, their oeuvre was profoundly critical of both the Iraqi regime on account of its cruelty, and the Iraqi people for their indifference to the country's future.

The model of criticism that their works reflected consisted of a number of simultaneously operating concentric circles, moving from the center outwards. First there is self-criticism, that is, the criticism that an intellectual expresses toward his fellow intellectuals and artists. Then there is criticism of the people. And finally there is criticism of the regime, often represented by managers at the protagonist's place of work. Occasionally there appear also secondary circles, such as criticism of one's family. However, since this particular circle is not always clearly expressed, it is not included in the model's basic version. This paper will deal with two of these circles; criticism of the people and criticism of the regime. The criticism in these circles is expressed via some unique artistic devices, as described below.

Diagram of the model of circles of criticism as reflected in the works under discussion

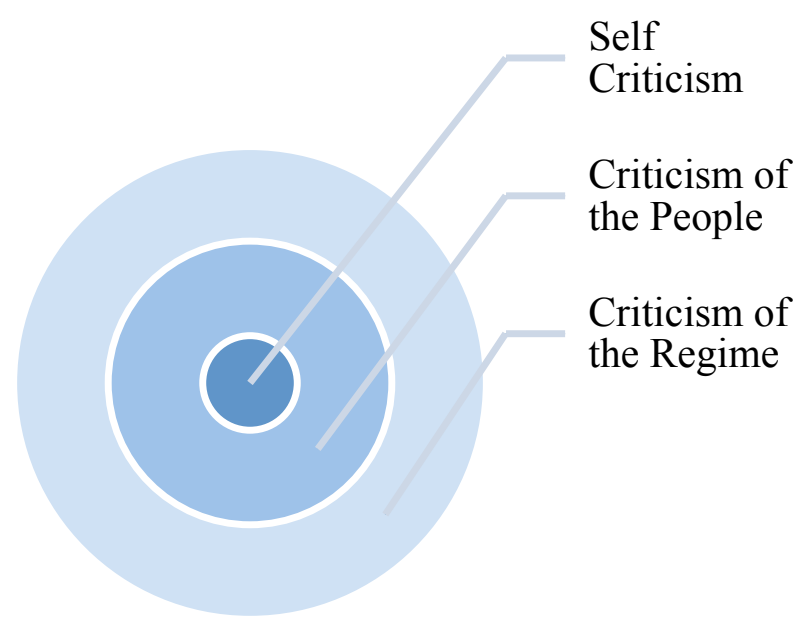

Circle of criticism of the regime

\footnotetext{
${ }^{7}$ The café where this group used to gather was closed by the Iraqi police, which feared that it would become a center of leftist activity. For more on this, see: Jabra, p. 175.
} 


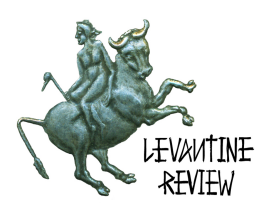

How, then, do Farmān and al-Haydari in their works describe their relationship with the Iraqi regime; a relationship that was mostly on a downhill trajectory? This relationship between leftist intellectuals and the regime is described metaphorically in their works as one between beast of prey and its victim, between hunter and hunted.

In Farmān's allegorical short novel Alam al-sayyid Ma 'rūf (Mr. Ma 'rūf's Pains) he describes the relationship between an educated, progressive man and his superiors at work who, of course, represent the regime. The smile of his supervisor at work is described a number of times as "a predatory smile" (ابتسامة مفترسة ${ }^{8}{ }^{8}$ in a way that makes it clear to the reader that this expression is a synecdoche, that is, a part that stands for the whole, in this case the man as predator. Furthermore, in a dialogue between the two character, the manager accuses the intellectual protagonist of not belonging to the human race: "I began to doubt if you were human" (بدأت اشك في انك من البشر), 9 thus dehumanizing and so delegitimizing the intellectual or, in the words of al- ' Azzawi, treating him like an animal. ${ }^{10}$

Imagery and historical allusions from the Arab and Muslim worlds also serve Farmān well in his description of the relationship between the leftist intelligentsia and the authorities: The protagonist compares himself to a jerboa being hunted by Arabs, that is to say a prey hunted by the regime. Here the author, by way of his main character, uses a historical tale in order to convey his message: In the Abbasid period the adherents of the shu 'übiyya, a cultural movement of non-Arab converts to Islam, accused the Arabs of hunting down jerboas and eating them; ${ }^{11}$ the protagonist of Farmān's short novel formulates a modern paraphrase of this accusation and says that today, in the twentieth century, the jerboas, that is, the intellectuals, are hunted relentlessly at every turn: الا ان القتل حاصل على اية حال ("the killing will inexorably take place, regardless of the circumstance.") ${ }^{12}$ Indeed, another intellectual in the story is "hunted" and killed in the course of the plot; and although the details of the murder remain unclear, the climate of persecution makes it reasonable to assume that the motives were ideological. ${ }^{13}$

The shu 'übiyya's accusations that the Arabs eat jerboas is not the only allusion that serves the author's purposes. Another element of history used by Farmān in his works is the Umayyad governor of Iraq, al-Hajjaj b. Yusuf al-Thaqafi (661? 714), who was known for his iron fist and for an infamous pronouncement in which he noted how blood would flow between the turbans and the beards. كل شيء بالدنيا تعود [...] حتى القتل الذي :Farmān alludes to this in the following passage

\footnotetext{
${ }^{8}$ Farmān, Alam al-sayyid Ma 'rūf, Beirut, 1982, pp. 35, 40.

${ }^{9}$ Ibid., p. 113.

${ }^{10}$ Al-'Azzawi, pp. 271-272.

${ }^{11}$ Al-Jāḥiz, Abū 'Uthmān 'Amr b. Baḥr, Kitāb al-ḥayawān (Book of Animals), Beirut, 1968, Part VI, Vol. II, p. 530.

12 Farmān, Alam al-sayyid Ma 'rūf, p. 123.

13 Ibid., pp. 123-124.
} 
تر اه اليوم تعود. نحن العر اقيين تعودنا عليه من زمان. من زمان الحجاج الذي رأى رؤوسا أينعت وحان قطعها ("Everything in the world is habit [...] Even the killing that you see today is habit. We Iraqis have long become accustomed to it, from the days of al-Hajjaj, who saw people merely as heads that had become ripe and suited for the slaughter." ${ }^{14}$ The allusion to the murderous al-Hajjaj suffices for Farmān's readers, who know the history of the Muslim Empire, to understand the speaker's attitude towards his rulers, whom he depicts as blood-thirsty animals.

Farmān's contemporary, the poet Buland al-Haydari, describes the harsh relations with the regime in even sharper terms, including descriptions of cruel tortures:

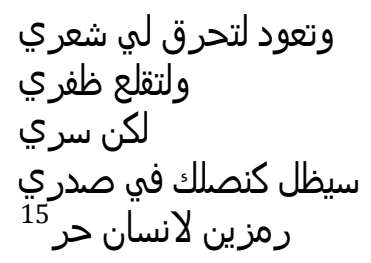

You will once more burn my hair And tear out my nail

But my secret

Will remain like your blade in my chest Two symbols for a free man [...]

And:

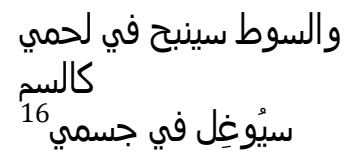

The whip will bark in my flesh Like venom Will penetrate into my body

The Iraqi intellectual who confronts the regime is placed in a dilemma: The moment he attacks the regime his life or, at best, his career are in danger. As the afore-quoted poem states, the regime's whip will penetrate his body like venom, in a manner that had become customary for the Iraqi regime in later decades. ${ }^{17}$

As part of al-Haydari's depiction of the relationship with the regime, he describes how the persecuted intellectual must struggle to survive; in order to do so, he must refrain from doing precisely what he is expected to do, namely to think and to warn. As al-Haydari puts it,

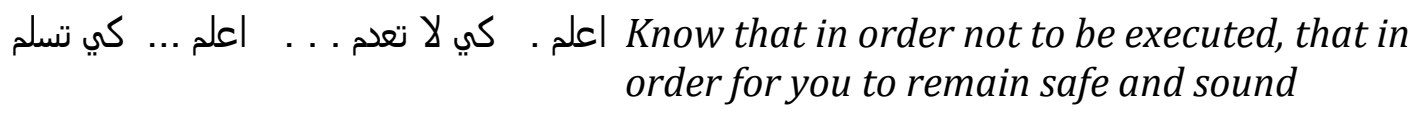

\footnotetext{
14 Farmān, Al- Makhāẹ, Baghdad, 1974, p. 89.

${ }^{15}$ Al-Haydari, "Sirr", Dīwān khuṭuwāt fì al-ghurba, al-a`māl al-kāmila, Cairo, p. 301 (First published in 1965).

${ }^{16}$ Ibid., p. 300.

${ }^{17}$ On corporal punishment under the Iraqi regime, see also: Al-Mașrīi, Ibrāhīm, Rașīf al-qatlā: mushāhadāt șahẫfì 'arabì fì al-'irāq (The Pavement of Murdered: Viewings of an Arab Journalist in Iraq), Beirut, 2007, pp. 187-191.
} 


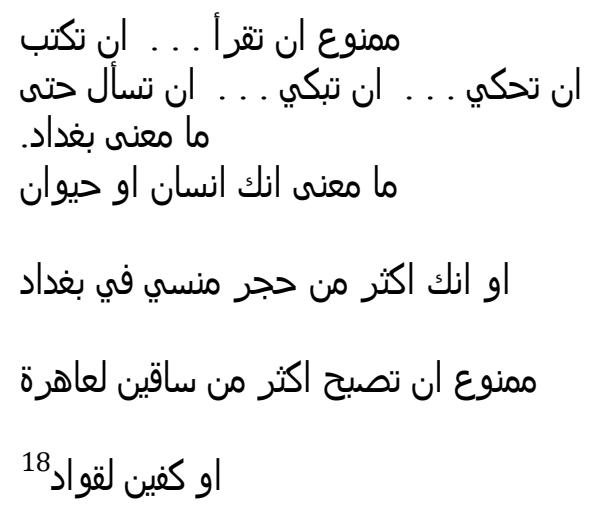

You must not read, or write

Or speak, or cry, or even ask

What Baghdad means.

What it means that you are a human being or an animal

Or that you are more than a forgotten rock in Baghdad

You must not become more than a whore's two thighs

Or a pimp's two hands

Based on this passage, and on the regime's order, Baghdadi intellectuals have no voice and no personality of their own. So as to fend off the gallows they must suppress and stamp out their very essence, namely their existence as intellectuals: They must not read or write, since their ideas pose a danger to the regime; they must not speak, for speaking brings ideas to life and could, so the regime fears, incite the people; they must not weep, and so are forced to ignore their most basic emotions as humans in the face of the horrors that they witness; furthermore, the status of intellectuals in Iraq has deteriorated to such an extent that their lives are, according to the poem, of no more significance than a prostitute's thighs or a pimp's hands. In other words, the intellectual must sell himself, like a whore who sells her body, to the ruler's whims. The poem also states that, for the regime, a human being, an intellectual, is worth no more than an animal or a forgotten rock in Baghdad. All three are trivial and irrelevant.

As part of the tension between the ruling class and the intellectual, the latter learns that the authorities rob him of even that most basic of human acts, the act of thinking that characterizes him. In al-Haydari's words,

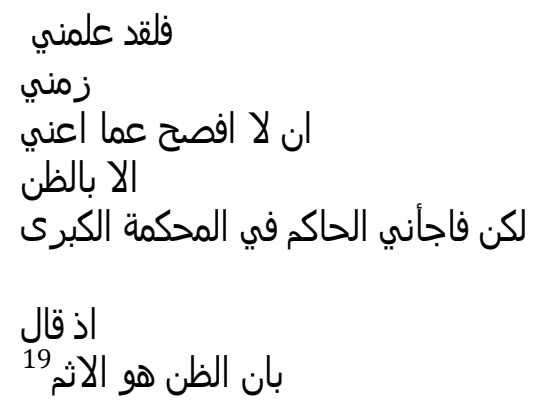

My time

Already taught me

Not to express what I mean

Except in thought

But the judge in the supreme court surprised me

When he said

That the thought was the crime

In other words, the very act of thinking is the most terrible of crimes, as far as the regime and its minions are concerned. The absurd of course lies in the fact

\footnotetext{
${ }^{18}$ Al-Haydari, "al-Madīna allatī ahlakaha al-șamt" ("City Destroyed by Silence"), Dīwān abwāb ilā albayt al-ḍayiq, al-a'māl al-kāmila, pp. 727-728 (first published in 1990).

${ }^{19}$ Al-Haydari, "al-Baḥth `an al-zaman al-majhūl" ("Search for Unknown Time"), Dīwān abwāb ilā albayt al-dayyiq, pp. 734-735.
} 


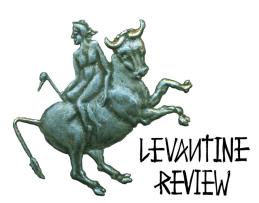

that the person who decides that thinking is a crime is a Supreme Court judge, that is, a man who one would expect to be enlightened himself and to understand the importance of enlightenment. This constitutes yet another stratum of criticism, going beyond an attack on the regime's cruelty. In fact, what is said here is that the judge is not as enlightened as he should be, since he continues to deprive men of their freedom instead of protecting those who wish to imbue their surroundings with fresh ideas and progress.

According to al-Haydari, intellectuals are so humiliated and scorned by the regime that they perceive themselves becoming slaves being dragged by their ears by cruel slave-masters, that is to say by the Iraqi authorities:

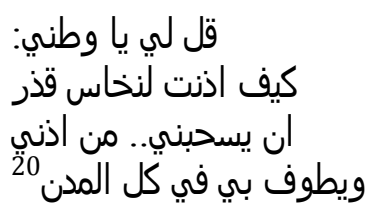

Tell me my homeland How could you let a filthy slave trader Drag me away by my ear And wander with me in all the cities

When an intellectual is "dragged" (by his ear) he can no longer think independently; the regime's violence and degrading treatment of its intellectual classes make thought and initiative impossible. Being forced to follow the regime (that is to say follow the slave trader) is a metaphor for the intellectual's helplessness vis-à-vis the regime, and his inability to adhere to his own opinions and maintain his own freewill.

Thus, by means of picturesque descriptions and a rich and biting system of images, often borrowed from the animal world, these writers depict in an artistic manner their relationship with the regime in Iraq; the circle of criticism of the regime thickens.

\section{Circle of criticism of the people:}

In the circle of criticism of the Iraqi people the intellectual expresses his disapproval of the people's way of life and ways of thought. This criticism is expressed using both conceptual and linguistic elements.

In Farmān's short novel $M r . M a^{\varsigma} r u \bar{f}$ 's Pains the well-educated protagonist, who is much better informed than most others in his environment and possesses an intimate knowledge of Arab history and both classical and modern Arabic, is harassed and ridiculed at the workplace, by both colleagues and superiors. He finds it difficult to reconcile the differences between himself and his backward surroundings. In one scene the protagonist ridicules his people who sit aimlessly in the streets, playing games and not doing anything: مساكين هؤ لاء لا يهمه الا الدومينو

\footnotetext{
${ }^{20}$ Al-Haydari, "al-Ḥudūd al-masrūqa" ("Stolen Borders"), Dīwān abwāb ilā al-bayt al-dayyiq, p. 694.
} 


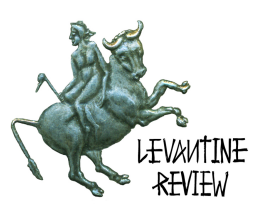

"Poor و الطاولي, لو جردوا من كر اسيهم ومناضدهم, وفرشت لهم الارض, لتربعوا امام لعبهر كالاطفال people; nothing interests them except for dominoes and backgammon [tawli in the colloquial dialect of Iraq]. Even if their chairs and tables were taken away from them, and if the bare ground were offered them instead, they would still sit with crossed legs before their games, like children.") ${ }^{21}$ The author's objective here is to criticize the Iraqi masses, who waste their time on useless tasks and ignore the things that matter; namely their problematic political situation. The image of immature children at play indicates the people's inability to act responsibly and to address the issues that Farmān considers truly important, namely what is happening in the country. According to Farmān the people do not oppose the corruption and bribery that are rife in the country's official institutions, nor do they seem to mind a government that cannot even pay its officials' salaries, as noted in another one of his novels, Zilāl 'ala al-nāfidha (Shadows on the Window.) ${ }^{22}$

In other works Farmān criticizes the ignorance evinced by part of the nation with respect to how to cope with social and political issues. He maintains that the people should engage actively in order to improve their living conditions: Every citizen should take the initiative and undertake to protest actively whenever he encounters an injustice, to take part in demonstrations, and even in revolutions.

One must keep in mind that those were times during which the Communists, who called for the creation of Dictatorship of the Proletariat, were persecuted in Iraq. And yet, in his short story "Hasīd al-raha" ("Harvest of the Grindstone") Farmān presents a dialogue between a man and a woman in the course of which the man tells the woman that he and his friends went on strike that day, in protest against the dismissal of three of their comrades. The woman is shocked and does not understand what he means:

He said [...]: "We went on strike!" ... (لقد اضربنا)

[...] A sound like a whisper escaped from her lips: "You went on strike (اضربت)?"

Then [...] he said enthusiastically: "Yes, we went on strike (اضربنا) ... That is a legitimate means for obtaining our rights".

She curled up like a porcupine [...] Feelings of sadness and disgust overwhelmed her and then she said slowly: "As if you are already sick of life and don't know how to throw it away".

He looked at her in rage and shouted: "Isn't it our right ... to defend ourselves?"

[She]: "But [why] in this way?"

\footnotetext{
${ }^{21}$ Farmān, Alam al-sayyid Ma 'rūf, p. 11. A similar criticism is made by the Syrian poet Nizar Qabbani (1923-1998), who speaks of those who spend their time in cafés, who have become a part of their chairs and are nothing but "stuffed crickets" (صر اصير محنطة): Qabbani,

(Diary of an Indifferent Woman), Beirut, 1973, p. 122.

${ }^{22}$ Farmān, Zilāl 'ala al-nāfidha, Beirut, 1979, pp. 115, 282, 285.
} 


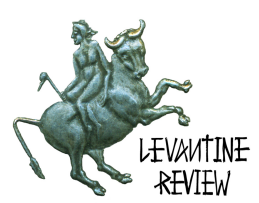

[He]: "Oh, you shouldn't see this as an exceptional act, as an activity that is against the law ... It is a peaceful way to fulfill our demand".23

Conceptually, Farmān in this dialogue shows that the laboring class no longer views the rulers as representing God's will. The argument between the man and the woman contradicts the religious (namely the Quranic) principle that class distinctions (and perhaps even gender inequality) are predetermined and permanent: "وَرَفَعَ بَغْضَكُمْ فَوْقَ بَغْ دَرَجَاتٍ" ("He has raised some of you above the others in degrees," says Quran 6:165.) ${ }^{24}$ Farmān rejects such a state of affairs in which a certain socioeconomic stratum must obey the managers-here representatives of the powers that be. In his view the risk that the strikers take by defying authority is smaller than the possible advantage of obtaining better working conditions should they remain resigned to their fate. This is the dialogue's conceptual message in Farmān's work.

Linguistically, the use of a different grammatical number, اضربنا ("we went on strike," in the first person plural) said by the man, in contrast to the woman's use of اضربت ("you went on strike," in the second person masculine singular,) reflects a difference in approach: The man has a collective awareness and uses the plural, in the well-known Communist tradition: We went on strike together. For Farmān and other Communist writers a collective awareness and mutual support are the solution to the problem posed by the hegemony of tyrants, for here as in many other works one's superiors at work often represent the authorities, as noted above. The woman, on the other hand, is ignorant and does not understand what the man is saying to her: She thinks that he went on strike by himself and that he will also have to bear the consequences by himself, not together with his comrades. The girl has no class consciousness; according to the text she has not internalized the concept of class discourse, of which she has no knowledge.

Farmān's account is critical towards the woman and her detachment from the social and economic realities around her. The dialogue is his way of expressing this criticism, both towards the regime, embodied by the superiors at work, and towards his society, which, from his perspective, is unmindful of how important cooperative action is for the good of society as a whole.

Farmān's political consciousness as a member of the Communist opposition and his call for action in the form of strikes and demonstration as a way to solve problems, while not yet shared by most of the common people, permeates his literary output. To wit, in his novel al-Qurbān (The Sacrifice,) ${ }^{25}$ and in the novel Zilāl 'ala al-nāfidha one of the figures speaks enthusiastically about participating in political action: “ يبدو انتا, نحن العر اقيين, لا نستطيع ان نعيش بدون سياسة [...

\footnotetext{
${ }^{23}$ Farmān ,"Hasīd al-raha", in Hasīd al-raha, Baghdad, 1954, pp. 24-25.

24 Quran 6:165.

${ }^{25}$ Farmān, al-Qurbān, Baghdad, 1975, pp. 10-11.
} 


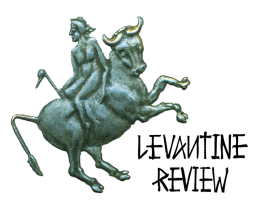

"انتا في السياسة نحصل على هويتنا المفقودة ("It seems that we Iraqis are incapable of living without politics [...] Through politics we regain our lost identity." ${ }^{26}$ In the works of Communist writers, intellectuals are usually described as being politically aware, but the common people are often presented as having no understanding and no awareness of what is happening in their own country.

Buland al-Haydari goes even further in his criticism of the people, comparing them to animals, that only open their eyes when the knife is placed on their throats:

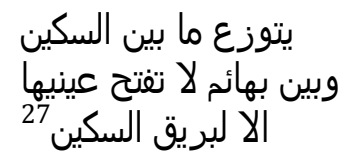

[The homeland] is split between the knife And beasts that do not open their eyes Except for the gleam of the knife

The people's inactivity and their indifference towards the state of their country cause the poetic narrator to produce this chilling description of the people, here equated to animals led to the slaughter, that awaken only too late, when the gleam of the ruler's knife is already at their throats.

The political and social situation drives the writers to the conclusion that the only solution is revolution, as one of the figures in Farmān's novel al-Makhād (Labor Pains) says:

For you the revolution is a birth that will give you a beautiful and healthy child, with no effort, no pain, no looking death in the eye. You'll dress it in the garment that it loves, that had been previously prepared for him. But I see the revolution as labor pains, in our case, harsh labor pains, from which anything can be expected: pain, tears, blood, an embrace with death. And the infant may turn out healthy, or crippled, or even dead. ${ }^{28}$

In other words, the revolution is a process of birth, whose results cannot be predicted, according to Farmān.

In addition to Farmān's suggested solution, the revolution, al-Haydari proposes another principle, that of "an eye for an eye." In his poem about the massacre that Saddam Hussein committed against the Kurds in the infamous 1988 Halabja chemical attacks, the poetic narrator predicts that at the end of the day the hangman's rope will end up wrapped around his own neck, that is to say around the neck of Saddam Hussein-as indeed things turned out eventually. ${ }^{29}$

\footnotetext{
${ }^{26}$ Farmān, Zilāl 'ala al-nāfidha, pp. 122-123.

${ }^{27}$ Al-Haydari, "al-Hudūd al-masrūqa", p. 695.

${ }^{28}$ Farmān, al-Makhād, Baghdad, 1974, p. 280.

${ }^{29}$ Al- Haydari, "Li-kay lā nansā" ("Lest We Forget"), Dīwān ākhir al-darb, al-ấmāl al-kāmila, pp. 769-773 (first published in 1993).
} 


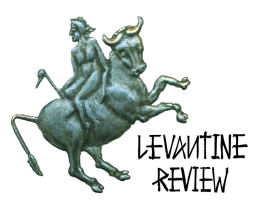

As victims themselves of the persecutions of the mid-twentieth century, the alternatives to the existing situation range from revolution for Farmān to revenge for al-Haydari, and a refusal to give in under the physical, mental and spiritual torments imposed by the regime.

\section{Summary}

By the very fact that in their writings they focus on the common man and the issues that concern him most immediately, al-Haydari and Farmān are representatives of Communist writers in mid-twentieth century Iraq. They define what they perceive as appropriate action, while making use of circles of criticism into which they aim their arrows from different angles; conceptual, esthetic, linguistic, grammatical, and stylistic, attempting to convey a message of collective awareness, at times contrasted with their society's lack of such awareness.

The Communist writers' two circles of criticism towards the regime and towards the people, as they appear in al-Haydari's and Farmān's works, lead to a message of change and revolution which, in contrast to the revolutions of the "Arab Spring" at the beginning of the second decade of the twenty-first century, did not pass beyond the stage of wishful thinking.

Adopting these devices, both conceptual and stylistic-linguistic, the Communist writers used the circles of criticism to paint a harsh picture of political persecution of the Communists by the authorities as well as a lack of sympathy on the part of the people, who at that time had not yet internalized the revolutionary discourse of the class struggle and so did not react to the message of regime change and "man's common good" as the leftist intellectuals had hoped. It is true that there were frequent coups that brought about regime change in Iraq of the mid-twentieth century, but ultimately those changes never solved the country's real problems. The Communists therefore tried to impose their own agenda. But they still did not succeed, both because the authorities did their best to prevent them from disseminating their ideas and their work, and because Iraqi society as a whole was still backward and unable to digest the Communists' message, and so showed no interest in supporting them.

It is therefore fair to say that the contribution of the Communist writers was not merely technical, in the sense that it showed the way to using novel forms of expression and new metaphors independently of the conventions of Classical Arabic writing. Rather, their more significant contribution was to provide an accurate and authentic depiction of the truly problematic relations that existed between intellectuals and the regime in the mid-twentieth century, and to criticize the values of their own traditional societies. 
the Communist writers, revolution, both political and social, was an inevitable, drawn-out and painful process whose results were hidden from view-not unlike the current unrest sweeping the Middle East, and the results of which remain to be seen. And just as the revolution in Farmān's work is compared to labor pains, so is it still too early to tell what kind of "infant" the current "Arab Spring" shall beget. But as for the revolution for which the Communist writers of mid-twentieth century Iraq yearned for, it is clear in retrospect that it did not reach fruition, and therefore it did not have the hopedfor effect of bringing about political and social change, despite the hopes that were pinned on it by opposition figures such as al-Haydari, Farmān and their contemporaries.

* Hilla Peled-Shapira is a Professor of Arabic at Bar-Ilan University. She writes on Kurdish poetry in Arabic, Arabic literature of exiles, and Communist Iraqi literature. 